\title{
USE OF SOLAR ENERGY (SOLARIZATION) FOR WEED CONTROL IN GREENHOUSE SOIL FOR ORNAMENTAL CROPS
}

\author{
M. MOYA and G. FURUKAWA \\ Cátedra de Terapéutica Vegetal, Facultad de Agronomía, \\ Universidad de Buenos Aires, Argentina
}

\begin{abstract}
Solarization using $50 \mu \mathrm{m}$ thick transparent polyethylene sheets for $3,10,22,32$ and 42 days was carried out in the greenhouse of a company which produces ornamental crops, in Jose C. Paz, Province of Buenos Aires, Argentina. Populations of the annual summer weeds Amaranthus hybridus and galinsoga (Galinsoga parviflora), and of the annual winter weeds spotted bur medick (Medicago arabica), chickweed (Stellaria media), sowthistle (Sonchus oleraceus) and twincress (Coronopus didymus) growing in soil that had been solarised for 42 days were significantly $(\mathrm{P}<0.05)$ less than in soil from control plots. Carnations growing in soil that had been solarised for 22 days had significantly $(\mathrm{P}<0.05)$ greater root weights, flower dry weights and numbers of flowers than carnations growing in unsolarised soil. High temperatures in the soil controlled annual weeds without hazards for workers or contamination of the environment.
\end{abstract}

Keywords: soil disinfection, plastic cover, weeds, ornamental crops, contamination.

\section{INTRODUCTION}

The use of solar energy for the disinfection of soil was developed in the 1970s in Israel (Rubin and Benjamin 1981; Horowitz et al. 1983) and for several years has been applied in this country at an experimental level and in intensive production (Verdejo et al. 1995; 1996). Achieving lethal temperatures for different pests in the soil (weeds, pathogens, nematodes and insects) allows effective control without hazard to workers and without contaminating the environment.

The objective of this study was to measure the effect of different periods of solarization against various annual weeds present in the soil of a greenhouse used for ornamental crops, and the impact of solarization on crop development and quality.

\section{MATERIALS AND METHODS}

This work was carried out on a property producing ornamental crops, in Jose C. Paz, Province of Buenos Aires, Argentina between 4 February and 22 March 1998.

Inside a greenhouse, six treatments were arranged in a randomised complete block with three replicates. The treatments were solarization for 3, 10, 22, 32 and 42 days and one untreated control plot. The soil was $30 \mathrm{~cm}$ deep and each plot occupied a surface area of $2.25 \mathrm{~m}^{2}$.

At the beginning of the experiment all plots were tilled and irrigated to field capacity. The plots to be solarised were then covered with $50 \mu \mathrm{m}$ thick transparent polyethylene sheets, laid close to the soil surface with their edges anchored in trenches along the side of plots.

Soil temperatures were measured at 5 and $10 \mathrm{~cm}$ depth with a digital electronic stem thermometer in solarised and untreated plots. Daily temperature inside and outside the greenhouse was measured with mercury thermometers at $1.5 \mathrm{~m}$ above the soil. 
The plastic sheets were removed after $3,10,22,32$ or 42 days of solarization, and the treated soil was placed in black polyethylene bags. Soil from the control plots was treated in the same way.

At the end of May the soil was placed in pots into which one seedling of carnation (Dianthus sp Telstar, variety Queen colour) per pot were transplanted. Observations of weed seedling emergence were made from then until harvest in the second week of September. When the crop was ready for harvest a representative sample of 30 pots per treatment was taken. For each plant, the dry weight of roots, leaves, stems and flowers was determined. A count of the number of inflorescences produced by each plant was made in each one of the treatments

Data were analysed using ANOVA of the randomised complete block design and differences between solarization treatments compared using Tukey pairwise comparisons at a significance level of $\mathrm{P}<0.05$.

\section{RESULTS AND DISCUSION}

At $5 \mathrm{~cm}$ depth, solarised plots reached temperatures $10.6^{\circ} \mathrm{C}$ higher than untreated plots, and at $15 \mathrm{~cm}$ depth the difference was $6.6^{\circ} \mathrm{C}$. Fig. 1 shows the temperatures reached in the different treatments during the course of the experiment.

\section{Effects on weed seedling emergence}

The temperatures reached under the polythene reduced the populations of the annual summer weeds Amaranthus hybridus and galinsoga (Galinsoga parviflora), and of the annual winter weeds spotted bur medick (Medicago arabica), chickweed (Stellaria media), sowthistle (Sonchus oleraceus) and twincress (Coronopus didymus) (Table 1). For spotted bur medick seedlings, 3 days of solarization appeared to lead to a large increase in seedling numbers in comparison with the untreated plots. The best treatment was solarization for 32 days, which reduced seedling numbers by $79 \%$ in comparison with the untreated control. Chickweed seedlings also increased after 3 days solarization. For this species, the optimum period of solarization appeared to be only 10 days, a treatment that reduced seedling numbers by $77 \%$ in comparison with the untreated control. Seedlings of sow thistle were dramatically reduced by longer periods of solarization, with no seedlings appearing after solarization periods of 32 or 42 days. Twincress seedlings decreased as a result of all solarization treatments greater than 3 days. The annual summer weed Amaranthus hybridus was also affected by solarization periods of over 3 days and the greatest effects were achieved by periods of 22 days or more. For the galinsoga, seedling numbers increased following 3 days of solarization, but solarization for 32 or 42 days appeared to prevent any emergence of seedlings.

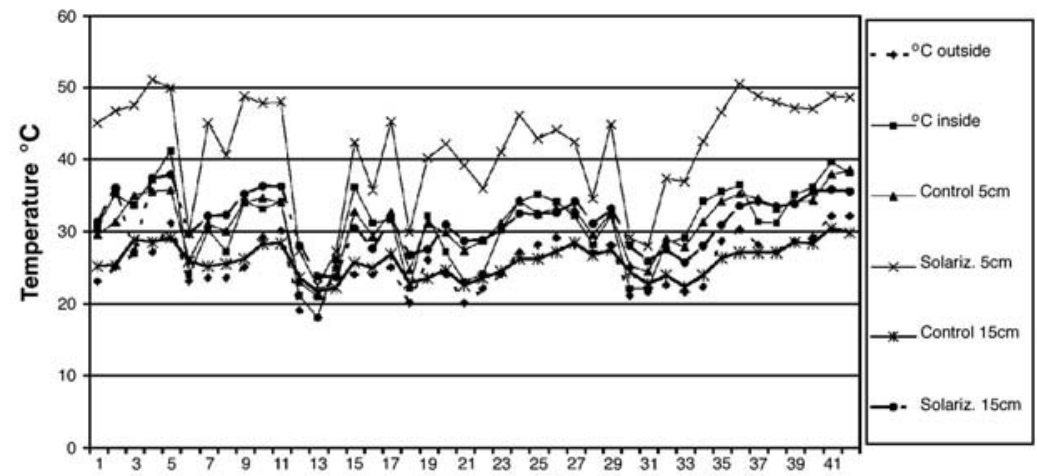

FIGURE 1: Daily temperature inside and outside the glasshouse and at 5 or 15 cm soil depth for solarised and unsolarised treatments during the course of the experiment. 
TABLE 1: Emergence of annual weeds (plants/m²) after 3, 10, 22, 32 or 42 days solarization compared to an unsolarized control.

\begin{tabular}{|c|c|c|c|c|c|c|}
\hline Treatments & $\begin{array}{c}\text { Medicago } \\
\text { arabica }\end{array}$ & $\begin{array}{l}\text { Stellaria } \\
\text { media }\end{array}$ & $\begin{array}{c}\text { Sonchus } \\
\text { oleraceus }\end{array}$ & $\begin{array}{l}\text { Coronopus } \\
\text { didymus }\end{array}$ & $\begin{array}{c}\text { Amaranthus } \\
\text { hybridus }\end{array}$ & $\begin{array}{l}\text { Galinsoga } \\
\text { parviflora }\end{array}$ \\
\hline 3 days & 800 & 489 & 156 & 267 & 89 & 267 \\
\hline 10 days & 222 & 67 & 156 & 200 & 89 & 133 \\
\hline 22 days & 133 & 156 & 67 & 89 & 44 & 67 \\
\hline 32 days & 67 & 89 & 0 & 89 & 44 & 0 \\
\hline 42 days & 200 & 111 & 0 & 89 & 44 & 0 \\
\hline Control & 311 & 289 & 267 & 378 & 200 & 133 \\
\hline \multicolumn{7}{|c|}{ Critical value for } \\
\hline SEM & 29.8 & 29.8 & 27.5 & 42.9 & 27.5 & 27.6 \\
\hline
\end{tabular}

${ }^{1}$ Values within a column that differ by more than this value are significantly different from each other $(\mathrm{P}<0.05)$.

Solarization appears to have a dramatic effect on the seeds of annual weeds, and this is related to the eco-physiology of weed seeds. High temperatures can reduce the dormancy of some seeds and this appears to explain those cases where brief periods of solarization resulted in the emergence of more seedlings. Longer periods of solarization appeared to either kill seeds or to induce dormancy. The seeds of annual summer weeds germinate when the soil temperature rises after winter and the annual winter weeds germinate as soon as the temperature of the soil falls after the summer. The correlation of the cycles of seasonal temperatures with the rupture of the dormancy and the promotion of germination has been observed in many annual species. (Egley 1986). Temperature has a great influence on physiological and biochemical processes; high temperatures can reduce the dormancy of some seeds or induce others to secondary dormancy. This explains why in some cases soil exposed to solarization had a larger number of weeds than the soil without treatment. Light is another important factor in the activity of weed seeds (Karssen 1982) but this was not investigated in this experiment.

\section{Effects on growth of carnations}

The seedlings transplanted to solarised soil tended to show an increase in the development and weight of the roots, stem, leaves and flowers (Table 2) in comparison with those transplanted into untreated soil. For root weights, the solarization treatments were significantly greater $(\mathrm{P}<0.05)$ than the control at 10,22 and 32 but not 3 or 42 days. For flower dry weights, solarization treatments from 10 days were all significantly greater $(\mathrm{P}<0.05)$ than the control. Significant differences were also obtained for the number of flowers obtained from the different treatments. Most flowers were obtained in soil solarized for 22 days (Table 2).

Other work has also found that solarization has a positive impact on crop productivity (Moya et al. 1997) and quality (Katan 1988). It has been shown that better development of plants and a higher number of flowers in ornamental crops is a result of greater activity of beneficial micro-organisms in solarized compared to unsolarized soils (Katan 1988). Solarized soil maintains the beneficial characteristics acquired for up to 2 years (Katan 1988; Mitidieri et al. 1995; Moya et al. 1995, 1996 ).

The application of chemicals like methyl bromide for the disinfection of soils is a high risk practice for people using this extremely toxic product. Solarization allows an effective control of annual weeds in crops and constitutes an alternative, nonpolluting method for the disinfection of soils against various soil-borne pathogens, such as Rhizoctonia solani, Fusarium oxysporum, Sclerotinia sclerotiorum and Sclerotium rolfsii. This helps to avoid the risk of environmental contamination and phytotoxicity and reduces the manpower required to remove weeds from ornamental crops that are sold in pots where manual weeding is the only form of control. 
TABLE 2: Dry weight of roots, stems and leaves, and flowers and the number of flowers after $3,10,22,32$ or 42 days solarization compared to an unsolarised control.

\begin{tabular}{|c|c|c|c|c|}
\hline Treatments & $\begin{array}{l}\text { Dry weight of } \\
\text { of roots }(\mathrm{g})\end{array}$ & $\begin{array}{c}\text { Dry weight of } \\
\text { stems and leaves }(\mathrm{g})\end{array}$ & $\begin{array}{l}\text { Dry weight of } \\
\text { flowers }(\mathrm{g})\end{array}$ & $\begin{array}{l}\text { Number of } \\
\text { flowers }\end{array}$ \\
\hline 3 days & 1.28 & 1.80 & 0.332 & 4.6 \\
\hline 10 days & 1.49 & 2.18 & 0.493 & 6.6 \\
\hline 22 days & 1.72 & 2.32 & 0.643 & 6.3 \\
\hline 32 days & 1.44 & 2.16 & 0.600 & 8.6 \\
\hline 42 days & 1.19 & 1.88 & 0.573 & 5.9 \\
\hline Control & 1.12 & 1.97 & 0.420 & 4.8 \\
\hline $\begin{array}{l}\text { Critical Value } \\
\text { for Comparison } 1\end{array}$ & 0.287 & 0.496 & 0.138 & 1.44 \\
\hline SEM & 0.083 & 0.143 & 0.0398 & 0.42 \\
\hline
\end{tabular}

${ }^{1}$ Values within a column that differ by more than this value are significantly different from each other $(\mathrm{P}<0.05)$.

\section{REFERENCES}

Egley, G., 1986. Seed germination in soil: Dormancy cycles. Rev. Weed Sci. 2: 67 - 89. Horowitz, M., Regev,Y. and Herzlinger, G., 1983. Solarization for weed control. Weed Sci. 31:170-179

Karssen, C.M., 1982. Seasonal patterns of dormancy in weed seeds. Pp 243-270 In: The physiology and biochemistry of seed development, dormancy and germination. Elsevier, Amsterdam.

Katan, J., 1981. Solar heating (solarization) of soil for control of soil borne pests.Ann. Rev. Phytopath. 19: $211-236$

Mittidieri, I. and de y Mitidieri, M., 1994. Efecto de la geodesinfección sobre la producción de plantines de tomate en invernáculo. Rivista di Agricoltura Subtropicale e Tropicale 88 (3): 539-545.

Moya, M., Verdejo, J. and Frezza, D., 1997. Soil disinfection by means of solar energy. International Congress For Plastics In Agriculture. Tel Aviv, Israel.

Rubin, B. and Benjamin, A., 1981. Solar sterilization as a tool for weed control. Weed Sci. Soc. Am. 39: 135.

Verdejo, J., Frezza, D., Fraguas, A.M. and Moya, M., 1996. La solarización en el control de las malezas. XIX Congreso Argentino de Horticultura, San Juan. p 25.

Verdejo, J., Moya, M., Fraguas, A.M. and Frezza, D., 1995. Evolución de la población de malezas en suelo solarizado. XX Congresso Brasileiro Da Ciencia Das Plantas Daninhas. Florianopolis, Santa Catarina. p 11. 